\title{
L.G. Mpedi
}

\section{THE ROLE OF RELIGIOUS VALUES IN EXTENDING SOCIAL PROTECTION: A SOUTH AFRICAN PERSPECTIVE}

\section{ABSTRACT}

This article reflects critically on the role played by religious networks - in particular the African Independent Churches or African Initiated Churches (AICs) - in enhancing social protection by means of informal coping mechanisms in the South African context. It also examines various factors that contribute towards informal social security dependency in AICs, namely the influence of the Constitution of the Republic of South Africa, the limited scope of social security coverage, the restricted family concept (underlying much of the formal system which does not reflect the family context in South Africa), African traditional values, and Christian principles. In addition, the article investigates the nature of the relationship between informal coping mechanisms (such as those in AICs) and formal social security, i.e. whether informal social security strengthens or weakens formal social security. It finally explores ways and means of strengthening informal social security, in particular in the wake of challenges such as HIV/AIDS, urbanisation and migration.

\section{INTRODUCTION}

This article reflects critically on the role played by religious networks - with specific reference to the African Independent Churches or African Initiated Churches (AICs) (for a discussion of the terms used to describe these Churches, see Bongmba 2003:77; Anderson 1995:283; Hayes 1992:139) — in enhancing social protection ${ }^{1}$ by means of informal coping mechanisms (sometimes referred

1 According to the Asian Development Bank (http://www.adb.org/SocialProtection/ default.asp), "social protection"

consists of policies and programmes designed to reduce poverty and vulnerability by promoting efficient labour markets, diminishing people's exposure to risks, enhancing their capacity to protect themselves against hazards and interruption/loss of income.

Prof. L.G. Mpedi, Associate Professor: Department of Mercantile Law, Faculty of Law, University of Johannesburg, Auckland Park Campus. E-mail: Igmpedi@ uj.ac.za. This contribution is based on a paper presented at the Max Planck Institute for Social Anthropology Workshop on Social Security in Religious Networks: Changes in Means, Contents and Functions, Halle/Saale, Germany, 10-11 November 2005. 
to as "informal social security") $)^{2}$ in the South African context. Although this article focuses on informal coping strategies in $\mathrm{AICs}$, it should be borne in mind that other religious networks (African traditional, Christian and Islam) have been and remain instrumental in providing social protection to needy persons in South Africa. The religious sector networks' direct financial contribution to welfare, relief and development programmes in South Africa is estimated at R1 billion per year (Louw \& Koegelenberg 2003:4).

The article examines factors that contribute towards informal social security dependency in AICs, including the influence of the Constitution of the Republic of South Africa (Act 108 of 1996) (hereinafter the Constitution), the limited scope of social security coverage, the restricted family concept (underlying much of the formal system which does not reflect the family context in South Africa), African traditional values, and Christian principles. In addition, it investigates the nature of the relationship between informal coping mechanisms (as found in AICs) and formal social security, i.e. whether informal social security strengthens or weakens formal social security. It finally explores ways and means of reinforcing informal social security, in particular in the wake of challenges such as HIV/AIDS, urbanisation and migration.

\section{AN OVERVIEW OF RELIGIOUS GROUPS IN SOUTH AFRICA}

There are diverse religious groups in South Africa (see Rautenbauch \& Goolam 2002; Bongmba 2003:11-12) including mainly African traditionalists, ${ }^{3}$ Christians, Hindus, Muslims and Jews. Nearly $80 \%$ of the South African population is Christian (About SA - The land and its people: http://www.info.gov.za/aboutsa/land people.htm). Various Christian Church Groupings include the AICs (e.g. the Zion Christian Church [ZCC]), Afrikaans Churches (e.g. the Nederduitsch Hervormde

2 See the paragraph on informal social security below.

3 African traditional religion has been described as follows:

Because the traditional religion of the African people has a strong cultural base, the various groups have different rituals, but there are certain common features. A Supreme Being is generally recognised, but ancestors are of far greater importance, being the deceased elders of the group. They are regarded as part of the community, indispensable links with the spirit world and the powers that control everyday affairs. These ancestors are not gods, but because they play a key part in bringing about either good or ill fortune, maintaining good relations with them is vital and they have to be appeased regularly by a variety of ritual offerings (About SA - The land and its people: http://www.info.gov.za/aboutsa/landpeople.htm). 
Kerk, the Uniting Reformed Church of South Africa and the Reformed Church in Africa) and other Christian Churches (e.g. the Methodist Church and the Church of the Province of Southern Africa [Anglican Church]). The AICs constitute the largest grouping of Christian Churches. Their existence is attributed to various nonexhaustive factors. First, Africans have cultural beliefs (e.g. belief in divinities, spirits, ancestors) (Kamara 2000:508; Bongmba 2003:11; Comaroff \& Comaroff 1986:4-6) and customs (e.g. polygamy) (see Norton 1941:53), practised in African traditional religion, which were to a large extent perceived as unchristian or unbiblical by Western Churches and missionaries (see, in general, Mazibuko 1996:249). The desire to incorporate local beliefs and customs into the church motivated the establishment of AICs (Bongmba 2003:78; Norton 1941:52). It could be argued that the AICs endeavour to combine African traditional values and Christian principles. Secondly, mainstream Churches neglected the physical and spiritual needs of their members (Bongmba 2003:79). The AICs are geared towards fulfilling African aspirations and meeting African needs (Anderson: http://artsweb. bham.ac.uk). Furthermore, the AICs were established as a result of

the general socio-political and cultural climate of discrimination, injustice, and economic marginalization that, in turn, encouraged the search for alternative spaces in which individuals and communities could grow spiritually, socially, economically, and emotionally (Bongmba 2003:79).

The emergence of AICs was also inspired by the quest for self-determination (Bongmba 2003:78; Norton 1941:52).

\section{THE ROLE OF VALUES, THE CONSTITUTION AND RELEVANT SOCIAL SECURITY LEGISLATION IN EXTENDING SOCIAL PROTECTION}

\subsection{Informal social security arrangements}

Numerous observations have been made about what (should) constitute(s) informal social security (see, for example, Olivier \& Dekker 2003:562). It is hardly surprising that there is no precise definition for informal social security (Olivier et al. 2004). However, two forms of informal social security arrangements can be identified, namely private household-based or kinship-based (e.g. intergenerational transfers) and member organisation-based or non-kinship-based informal coping strategies (e.g. burial societies). Various factors contribute towards informal social security dependency. 


\subsubsection{The influence of the Constitution}

In the first instance, the Constitution as the supreme law of the country (the preamble, ss. $1[\mathrm{c}]$ and 2 of the Constitution) embraces a series of values including human dignity, the achievement of equality as well as the advancement of human rights and freedoms (s. 1 of the Constitution). These values are important in the process of social security provision because they to a large extent give meaning to the socio-economic rights entrenched in the Constitution (Olivier et al. 2003:61). ${ }^{4}$ The abovementioned values are concurrent with equally important values such as those originating from African culture. One such value, ubuntu, is mentioned in the postscript of the Interim Constitution of the Republic of South Africa (Act 200 of 1993). Ubuntu "broadly means that an individual's humanity is expressed through his relationship with others and theirs in turn through recognition of his humanity" (Barrie 2000:271). ${ }^{5}$ The concept of ubuntu has also been alluded to in the White Paper for Social Welfare (General Notice 1108 in Government Gazette No. 18166 of 1997) as a value permeating the social security context. ${ }^{6}$

Secondly, the right of access to social security (i.e. social insurance and social assistance) for every person in South Africa is entrenched as a fundamental right in the Constitution (s. 27[1][c] of the Constitution). The State has a duty to take reasonable legislative and other measures to achieve the realisation of the right of access to social security (s. 27[2] of the Constitution). This duty is, however, subject to the availability of resources (s. 27[2] of the Constitution). The obligation to provide (access to) social security is not restricted to the State (see, in general, Chirwa 2002; Pieterse \& Van Donk 2002); it also

4 As pointed out by the Constitutional Court in Government of the Republic of South Africa v. Grootboom 200011 BCLR 1169 (CC) paragraph 23:

There can be no doubt that human dignity, freedom and equality, the foundational values of our society, are denied those who have no food, clothing or shelter. Affording socio-economic rights to all people therefore enables them to enjoy the other rights enshrined in the Bill of Rights. The realisation of these rights is also critical to the advancement of race and gender equality and the evolution of a society in which men and women are equally able to achieve their full potential.

5 See Mokgoro (1997) for the meaning of the concept of ubuntu and the social values it represents.

6 The principle for caring for each other's well-being will be promoted, and a spirit of mutual support fostered. Each individual's humanity is ideally expressed through his or her relationship with others and theirs in turn through a recognition of the individual's humanity. Ubuntu means that people are people through other people (Chapter 2, par. 24). 
covers the family and the community at large. The State's duty is supplementary in nature. ${ }^{7}$ It is believed that this approach encourages intra-family and intra-community informal support mechanisms.

Lastly, the Constitution expressly prohibits unfair discrimination, whether direct or indirect, against any person in South Africa on the basis of such person's religion (s. 9[1] of the Constitution). ${ }^{8}$ In addition, it guarantees everyone's right to freedom of religion (s. 15[1] of the Constitution), ${ }^{9}$ assembly (s. 17 of the Constitution) and association (s. 18 of the Constitution). Furthermore, the Constitution provides that persons belonging to a religious community may not to be denied a right, with other members of that community, to practise their religion and to form, join and maintain religious associations (s. 31[1] of the Constitution).$^{10}$ The aforementioned rights are not absolute. They should be exercised in a manner consistent with any provision of the Bill of Rights (s. 31[2] of the Constitution) and are subject to the limitation clause. ${ }^{11}$ In interpreting these rights, South African courts have an obligation to promote the values that underlie an open and democratic society based on human dignity, equality and freedom (s. 39[1][a] of the Constitution). Such values might embrace those of both the African tradition and the Christian religion. The aforementioned freedoms imply that members of AICs are free to form and participate in informal coping mechanisms as part of their religious practice without any fear of being unfairly discriminated against by any person or even the State. This is, of course, subject to the fact that such practices are not in conflict with the Constitution.

$7 \quad$ See McKendrick \& Dudas (1987:184 \& 193) and Government of the Republic of South Africa v. Grootboom 200011 BCLR 1169 (CC) (at para. 15).

8 See Van der Vyver (1999:664-668) and Prince v. President of the Law Society, Cape of Good Hope 2002 (3) BCLR 231 (CC).

9 See $S$ v. Solberg 1997 (10) BCLR 1348 (CC).

10 Also see s. 235 of the Constitution.

11 Section 36 of the Constitution makes provision for the limitation of religious freedoms as follows:

(1) The rights in the Bill of Rights may be limited only in terms of law of general application to the extent that the limitation is reasonable and justifiable in an open and democratic society based on human dignity, equality and freedom, taking into account all relevant factors, including - (a) the nature of the right; (b) the importance of the purpose of the limitation; (c) the nature and extent of the limitation; (d) the relation between the limitation and its purpose; and (e) less restrictive means to achieve the purpose. (2) Except as provided in subsection (1) or in any other provision of the Constitution, no law may limit any right entrenched in the Bill of Rights (Christian Education of South Africa v. Minister of Education 2000 (4) SA 757 [CC]). 


\subsubsection{Limited scope of social security coverage}

Social security coverage in South Africa is limited (see Olivier \& Kalula 2004:33). The South African means-tested social assistance ${ }^{12}$ benefits are targeted at a select category of persons (see the Social Assistance Act 13 of 2004 and Mpedi et al. 2003:197). Despite being needy, such persons are sufficiently young, disabled or old not to work. The effect of this approach to social assistance provisioning is that unemployed persons who do not fit into one of the foregoing categories or never contributed to the unemployment insurance scheme or exhausted their unemployment insurance benefits are left at the mercy of poverty, as there are no universal benefits and/or State-financed benefits (specifically targeted at unemployed persons) such as unemployment assistance. ${ }^{13}$ Social insurance schemes tend to be biased towards the formal sector. Access to social insurance schemes depends to a large extent on a formal employer-employee relationship. In the wake of the high unemployment ${ }^{14}$ and huge informal employment (see, for example, Valodia 2001:871), such schemes accordingly exclude and marginalise many groups and categories of persons as well as their dependants.

Secondly, concepts and definitions used in these schemes tend to be narrow and in most instances limit the scope of their reach. For example, the definition of a spouse in the case of dependants' benefits is often couched in narrow terms to prefer the common law wife rather than a customary or religious law wife. This approach results in the exclusion of women regarded as spouses in customary and religious law - particularly in polygamous marriages. ${ }^{15}$ The

12 Social assistance, as defined by the Committee of Inquiry into a Comprehensive System of Social Security for South Africa (2002:36), means "state provided basic minimum protection to relieve poverty, essentially subject to qualifying criteria on a non-contributory basis".

13 Central to this problem lies the fact that:

South Africa's current welfare state regime is premised on the belief that people need support through the state or market only when too young or too old to work, or during brief periods of unemployment (in between long periods of employment when they are able to contribute to unemployment insurance) (Nattrass \& Seekings 1997:467).

14 Unemployment in South Africa, based on the official definition, was estimated at 23\% in September 2007 (Statistics South Africa 2007:ii).

15 Section 38(7)(c) of the previous Unemployment Insurance Act 30 of 1966, for example, defined a "widow" as including "any woman who was a participant in a customary union according to indigenous law and custom, where neither the man nor the woman was a party to a subsisting marriage". This implied that a widow who was a party to a customary union was able to benefit as long as there was no other wife married in terms of common law. If there was a subsisting common law marriage between the 
exclusion or ranking of spouses in a polygamous union - which is considered a valid form of marriage by the African traditional religion as well as by the AICs could be directly linked to the common law definition of marriage. The common law defines "marriage" as a "union between a man and a woman to the exclusion of all others while it lasts" (see, for example, Seedat's Executors v. The Master [Natal] 1917 AD 302 at 309). This definition implies the Christian view of marriage (see, in general, Fitzpatrick 1900:259; 1901:157). In common law a polygamous union is considered contra bonos mores (against public morals) (Church 1982:297; Levin 1939:49).

\subsubsection{Restricted family concept}

In its narrowest sense "family" includes the father, the mother and the children (Songuemas 1967:20; Isizoh 2003). This Eurocentric concept of family (Folbre 1993:6) is discernable in some South African social security laws (e.g. Unemployment Insurance Act 63 of 2001) (see Olivier 2003:305-308 \& 310; Olivier 2001:283). In an African traditional society "family" has a wider significance:

It comprises a whole group of persons: the head of the family with his wives and his children, and grandchildren, and also his brothers and his sisters with their wives and children, his nephews and nieces, in a word, all those persons who descend from a common ancestor (Isizoh 2003).

As a result, the word "extended family" is frequently used instead of "family" when referring to an African family (see, for example, ljere 1967:27). The narrow concept of family excludes, for example, the de facto dependants of a deceased contributor, as most social insurance schemes in South Africa provide survivors' benefits to de jure dependants only.

\subsubsection{Black African traditional values}

The majority of black Africans are guided by African traditional values, which are embraced and respected by nearly all AICs, and which include the following: hlonipa ("respect"), simunye ("we are united/one") ${ }^{16}$ and reciprocity. First, African traditional values require individuals to treat each other with respect. This does not imply that there is a lack of hierarchy in (communal) African societies. Children, for example, are required to relate with senior members of the

deceased contributor and another woman other than the customary law wife, it meant that the common law wife would benefit to the exclusion of all others.

16 Simunye is all about the spirit of oneness which is a value derived from African traditional religion (Isizoh 2003). 
society with respect irrespective of whether they know them or not or whether they are related to them or not. Respect manifests itself in many ways in African societies. ${ }^{17}$ Providing for destitute family members, subject to the condition that the provider has the means to do so, could be interpreted as a sign of respect. Abandoning one's destitute family members (especially parents and, to some extent, grandparents) is or could be considered disrespectful. A person who does so risks the wrath of ancestors which could include bad luck. ${ }^{18}$ The curse of older persons is feared in African culture and cursed children may be considered socially ostracised (ljere 1967:17). ${ }^{19}$

Secondly, simunye emphasises group solidarity (Isizoh 2003), i.e. fathoming life as a unit (see Louw 2001:16). It should be stressed that:

[A]s a people, Africans emphasize groupness, sameness, and commonality. Rather than the survival of the fittest and control over nature, the African worldview is tempered with the general guiding principle of the survival of the entire community and a sense of cooperation, interdependence, and collective responsibility (Cobbah 1987:320).

It is partly on account of this value that Africans are willing to sacrifice for the welfare of a group (e.g. family or community) (Isizoh 2003). Furthermore, there is a close relation between this value and the general concern for the welfare of weaker members of the family or the community (e.g. the sick and the aged). ${ }^{20}$ It must

\section{According to Sudarkasa (1980:50) respect}

manifests itself in greetings, bows, [courtesies] and other gestures signalling recognition of seniority; it manifests itself in knowing when to be seen and not heard; it requires acknowledgement of and submission to persons in authority.

18 This statement should be understood within the context that:

Ancestors are thought to mete quick and severe punishment on people who disregard the hallowed traditions of the community, or infringe taboos and norms of acceptable behaviour in society. Africans, therefore, try to strictly observe such taboos and norms, thereby ensuring peace and harmony in their relationship with one another, with ancestors and other supernatural beings (Ejizu s.a.: http://www.afrikaworld.net/afrel/community.htm).

19 It should be mentioned that culturally children have to respect their parents as they are their ancestors on earth. They will, in any event, proceed as such when they depart this world.

20 As Isizoh (2003) puts it:

The sick are not left alone; the aged are not abandoned in 'Old People's Home'. They live with the members of their families. Euthanasia is not considered an option to end the pains of these weak members of the society. They are loved and cared for until they die and join the dead family members. 
be emphasised that laziness is discouraged in African societies. Mokoduo go tsosiwa o o itsosang is a Setswana expression, according to which assistance is given to those who (attempt to) help themselves.

Thirdly, reciprocity - similar to other traditional principles — "underlie[s] and undergird[s] interpersonal behavior in the family and the wider community in most indigenous African societies" (Sudarkasa 1980:50). This principle is of great significance in African societies because without it other principles (e.g. respect) would not last (Sudarkasa 1980:50). In accordance with African tradition, "it is expected that generosity will prevail, especially among relatives, but it is also expected that good deeds will be reciprocated either in the short or in the distant future" (Sudarkasa 1980:50).

In addition, it should be noted that African traditional values - when viewed from a social security perspective - underlie the individuals' participation in informal coping strategies. Consequently, informal coping strategies could be considered a means whereby individuals can endeavour to fulfil their cultural responsibilities.

\subsubsection{Christian principles and teachings}

The Bible does not use the term "social security". However, it may be inferred from the Bible that the church and individuals have social obligations towards the needy and the poor. Holy Scripture instructs the church to "honour widows who are truly widows" (I Timothy 5:3). ${ }^{21}$ It requires one to "do good to everyone" (Galatians 6:10) and not to "grow weary of doing good" (Galatians 6:9). Furthermore, it forbids one from withholding good from those who deserve it, when it is in one's power to act (Proverbs 3:27). In addition, it provides that: "It is more blessed to give than to receive" (Acts 20:35). The Bible allows the church and individuals (i.e. believers) to help needy persons in their endeavour to meet their social obligations. The church's efforts to fulfil its social responsibilities are primarily directed at fellow Christians (Harris 1990; Schirrmacher 1997) and are "largely supplemental to that of the family" (Harris 1990). The church's duty to honour true widows is subject to the following conditions. First, if a widow has children or grandchildren, the church should teach them how to show godliness to their own household and how to honour their parents (I Timothy 5:4). Secondly, the widow who is eligible for the church's welfare measures should not be less than sixty years (I Timothy 5:9). Lastly, the church

21 Reading from I Timothy 5:3-16, it would appear that a "true widow" is a widow who is (a) "left alone" (in the sense that she has no children or grandchildren and relatives), is (b) "not less than sixty years of age" and (c) "has set her hope on God and continues in supplications and prayers night and day". 
should allow any believing woman to care for her widowed relatives (I Timothy $5: 16)$. Thus the church should not be burdened so as to allow it to "care for those who are really widows" (I Timothy 5:16). An individual, on the other hand, has a duty to provide first for his/her family (I Timothy 5:8,16), then for members of the household of faith (Galatians 6:10) and lastly for the world (Harris 1990; Schirrmacher 1997). Notwithstanding the abovementioned social duties, the Bible requires individuals to do so if they are able to provide for themselves. This can be inferred from its warning against idleness. According to the Bible: "If anyone is not willing to work, let him not eat" (II Thessalonians 3:10). In addition, Holy Scripture issues a warning against folly:

Go to the ant, you sluggard; consider its ways and be wise! It has no commander, no overseer or ruler, yet it stores its provisions in summer and gathers its food at harvest. How long will you lie there, you sluggard? When will you get up from your sleep? A little sleep, a little slumber, a little folding of the hands to rest - and poverty will come on you like a bandit and scarcity like an armed man (Proverbs 6:5-11).

From a social security perspective, this parable advises individuals to initiate measures and schemes to mitigate or alleviate social risks while and when they can.

Biblical principles and teachings may, to some extent, be likened and linked to the African traditional values discussed above. The Bible requires individuals to respect/honour their parents (Leviticus 19:3; Exodus 20:12) and the elderly (Leviticus 19:32). It also challenges persons to love their neighbours (see Leviticus 19:18; Luke 10:33-37; Proverbs 3:27-28). It is argued that this could be interpreted as a challenge to treat fellow human beings with compassion (see, for example, Luke 10:33-37). Both Christian principles and African traditional values promote a sense of belonging among individuals. Such sense reassures a member of an AIC that he/she is not alone. Instead, he/she is surrounded by brothers and sisters of the AIC who will come to his/her aid in times of need. To prepare for the time of need, many AICs have their own informal coping schemes such as burial societies. Membership of these schemes is often restricted to members of the Church. ${ }^{22}$ African traditional values and Christian principles are thus instrumental in fostering informal social security dependence among members of AICs.

22 The Zion Christian Church (ZCC), for example, has the ZCC Burial Society established for its members. 


\title{
3.2 Relationship between informal and formal social security
}

What is the nature of the relationship between informal social security measures (such as those in religious networks) and formal social security? In an attempt to answer this question, the following factors must be examined.

\subsubsection{The philosophy underlying social security provisioning in South Africa}

The philosophy underlying general social security provisioning in South Africa has always been, and remains as follows:

\begin{abstract}
While the state accepts a duty to take measures to prevent social suffering on the part of its citizens and for making a selective contribution to relieving and combating social distress, this is viewed as a supplementary responsibility. The major onus lies on the person himself, his family and the community (see McKendrick \& Dudas 1987:193).
\end{abstract}

The South African Constitutional Court in Government of the Republic of South Africa v. Grootboom (2000 11 BCLR 1169 (CC) (at para. 15)) pointed out that parents have a primary duty to provide shelter to their children and the State has an obligation to provide that shelter if parents fail to do so.

This ideology, on the one hand, echoes to some extent that found in African traditional values and Christian principles (and teachings) relating to family and community involvement in their endeavours towards social welfare provisioning. The legal duty to provide filial care, according to the South African legal system (see, for example, s. 15 of the Maintenance Act 99 of 1998), supports these values. At law, parents have a duty to support their children and vice versa. In some instances, grandchildren may claim maintenance from their grandparents and vice versa. The duty to maintain is, nonetheless, subject to the conditions that the person claiming maintenance lacks the means to support him-/herself and that the person from whom maintenance is claimed has the resources to provide it.

On the other hand, this ideology envisages a partnership between the State and the community (McKendrick \& Duda 1987:186; Bak 2004:81). This is acknowledged by the White Paper for Social Welfare (Chapter 2, para. 30):

In view of fiscal constraints, low economic growth rates, rising population growth rates and the need to reconstruct social life in South Africa, the Government cannot accept sole responsibility for redressing past imbalances and meeting basic physical, economic and psycho-social needs. The promotion of national social development is a collective responsi- 
bility and the co-operation of civil society will be promoted. The Government acknowledges the contributions of organisations in civil society in meeting social service needs and in promoting development. The promotion of civil society is critical in building a democratic culture. Civil society includes the formal welfare sector, which is state-subsidised, religious organisations delivering welfare services, non-governmental organisations, which are currently not statesubsidised (also referred to as the informal welfare sector), the business sector, and informal social support systems and community networks.

In view of the foregoing, it could be argued that the present dual social security system (i.e. a system in which informal and formal social security mechanisms operate side-by-side) in South Africa is to some extent a result of the philosophy underlying social security provisioning.

\subsubsection{Informal social security mechanisms as the basis for the distributional impact of the social assistance scheme}

Traditionally, children and spouses contribute(d) to the socio-economic welfare of the family at large by performing tasks such as looking after family livestock, cultivating land, and gathering and preparing food (see Kokole 1994:75-76; Clay \& Van der Haar 1993:67-83). In addition, children serve(d) as some form of old-age insurance for the parents (see Kokole 1994:75). Much of this traditional environment is negatively challenged by unemployment, urbanisation and migration. Rising unemployment makes it difficult for the unemployed to provide for destitute members of their families. Urbanisation and migration affect the effectiveness and impact of traditional intergenerational support. Consequently, informal coping mechanisms (i.e. intergenerational transfers) serve as a platform from which formal social security schemes (in particular, the social assistance scheme) can operate. For example, the means-tested social assistance grants (i.e. the old-age grants) are often used for the welfare of the entire (extended) family (see Bertrand et al. 2003; Duflo 2003). This trend implies the co-existence of informal coping strategies and formal social security schemes (at least in the case of social assistance).

\subsubsection{Complementary or subsidiary role of informal coping strategies}

It is increasingly accepted that informal coping mechanisms are generally complementary or subsidiary to formal social security schemes (Olivier \& Mpedi 2003; Maes 2003; Kaseke 2002) as those who make use of these mechanisms (in particular those who are member organisation-based, e.g. burial societies) 
are to a large extent excluded from formal schemes (see, for example, Olivier \& Dekker 2003). Furthermore, the risks covered, the benefits provided, the $f i-$ nancing and the administration of the informal social security schemes are organised to suit the needs of their members (see Olivier et al. 2004): (a) Risks - members of informal social security schemes are mostly concerned about the immediate risks (e.g. providing for an empty stomach) and not long-term risks (e.g. old age); (b) Benefits - informal social security coping arrangements, apart from providing cash and/or benefits in kind, make provision for so-called "crash" benefits; ${ }^{23}$ (c) Financing - informal coping strategies are financed by members' contributions without the benefit of employer contributions, and (d) Administration - complex administrative and institutional framework of formal schemes such as the investment of reserves and expensive record-keeping is not necessary in informal social security arrangements.

\subsection{Influence of (new) risks and resources ${ }^{24}$}

HIV/AIDS has reached pandemic levels in South Africa. According to UNAIDS/ World Health Organization, 5,3 million people in South Africa were estimated to be HIV positive at the end of 2003 (UNAIDS/World Health Organization 2004:23). This startling figure poses a serious threat to informal social security schemes in the country. Informal social support networks have proved to be major players in cushioning the negative impact of HIV/AIDS on individuals, families and communities:

Availability and accessibility of informal social support mechanisms is crucial for successful recovery from a death of an adult female in the household. Informal social support mechanisms refer to the inter-household relationships between the household and community members, friends, relatives, and neighbours. In times of stress, households usually resort to these relationships for help on the basis of trust and reciprocity. Traditionally it is assumed that the extended family, and the community at large assist the household socially, economically, psychologically and emotionally ... households experiencing income stress due to HIV/AIDS, send their children to live with relatives ... Relatives will then be responsible for meeting the children's food requirements (Mutangadura 2001:4).

23 "Crash" benefits can be explained, for example, as a situation whereby

a group of persons may collectively build a home, plough a field, harvest a crop, or clear a field, completing the task in a single day; the payment of cash, even if available, might require the recipient to wait a long time before his felt needs could be met (Gerdes 1975:224).

24 This section partly draws from Oliver \& Mpedi (2003). 
It should also be noted that:

[T] he role played by family as a safety net is by far the most effective community response to AIDS crisis. Affected households in need of food send their children to live with relatives. Relatives are then responsible for meeting the children's food and other requirements. The preparation of food and agricultural work on the affected household's land and overseeing livestock may well be carried out by another family member or neighbour, in addition to their own tasks (International Labour Organization 2000:9).

Although the importance of informal support mechanisms to victims of HIV/ AIDS in South Africa cannot be stressed enough, one important fact remains: If HIV/AIDS continues to prevail unabated in South Africa, the informal support mechanisms are bound to fail in the long term (see Mpedi 2004:262-264). The increasing number of child-headed households is a sign that kinship-based support mechanisms are under stress (see Clark 2000:310).

Secondly, urbanisation and migration, fuelled by industrialisation and globalisation, pose a serious threat to the traditional values that form the basis of informal social security (see, for example, ljere 1967:34; Apt [s.a.]). This assertion mainly stems from the fact that

[U]rbanization alters individual's values, attitudes and his or her patterns of interactions and the prevailing cultural breakdown of the traditional social order and ends by undermining the traditional ability to support, integrate and provide meaning to life in one's declining years (Apt 2000).

The point is that when people migrate to urban areas they tend to adopt new ways of life which are characterised mainly by individualism and little respect for culture and its values (Malhotra \& Kabeer 2002:14). Above all, they interrupt the physical support of family or community (Apt 2000).

Furthermore, the aged are, culturally speaking, the source of wisdom and a moral beacon for the young and the middle-aged (Songuemas 1967:22). This has, however, changed over the years. ${ }^{25}$ Education is often cited as a contributing factor to this change. The issue is: "[E]ducation is seen to have replaced age as the barometer of wisdom and marker of status" (Malhotra \& Kabeer 2002:14). Increased access to formal education has ushered in new values based on educational accomplishments (Malhotra \& Kabeer 2002:14). For example:

Instead of status based on, say, age there emerged status based on literacy. Instead of classes emerging from the question, 'who owns what?' Class formation now responds to the question, 'who knows what?' (Okolo s.a.).

25 It is on account of this change that the society, politicians and the clergy are now talking about the need for moral regeneration in South Africa (see, for example, Roberts 2000). 
Consequently, the importance of the elder as a source of wisdom and guidance is of less significance to younger generations (Malhotra \& Kabeer 2002: 14). They thus face a different future to that of their grandparents (Malhotra \& Kabeer 2002:14).

Lastly, the continued existence of most member organisation-based informal schemes is threatened mainly by a lack of the necessary management skills and weak enforcement and compliance mechanisms. This renders them vulnerable to abuse (Olivier et al. 2004).

\subsection{Some suggestions for the future}

As indicated in this article, informal social security supplements formal social security schemes. Accordingly, informal schemes suit the State's ideology of social security provisioning. Similarly, informal coping strategies should not be glamourised (as a solution to the South African social security woes) nor construed as a license for the government to renounce its duty to provide for the poor and the vulnerable (Olivier et al. 2004). These strategies are imperfect due to a large extent to their susceptibility to new risks (e.g. HIV/AIDS, urbanisation and migration) and resources (e.g. education). Nevertheless, African traditional values and Christian principles, rising social security costs as well as the unavailability of resources, make informal coping mechanisms an indispensable component of a social security system. In any event, informal coping mechanisms (as those in the church and the community) used to be the mainstay of social security provisioning before the State took over. To this end, it is crucial that this article echo the call that informal coping strategies be strengthened (see, for example, Olivier \& Dekker 2003:587-591).

Strengthening kinship-based informal coping strategies is easier said than done. Nonetheless, preserving cultural and Christian values by means of educational campaigns (such as the moral regeneration drive) could be an ideal starting-point. In fact

[T]he answer to the challenges posed by the changes in African societies lies not in regretting good modern developments, not in looking backwards, but in studying what values have permanent validity, so that they should in some suitable form be saved and an acceptable synthesis with what is good in the new be worked out (Isizoh 2003).

As far as member organisation-based coping strategies are concerned, the following incomplete list of measures needs to be considered: (a) Capacity building - training is essential to improve the managerial skills and investment abilities of members of informal social security schemes; (b) Financial support - subsidies to enhance the financial base of informal social security 
schemes, and (c) Other assistance - technical assistance to help informal social security schemes manage risks (e.g. being under-funded and/or over-exposed) (Olivier et al. 2004).

\section{CONCLUSION}

This article focused mainly on the AICs, religious networks which, by means of informal coping strategies, play an important role in the South African social security system. The threat posed by risks such as HIV/AIDS, urbanisation and migration should not be ignored. For that reason, there is a need for the protection and rejuvenation of African traditional values and Christian principles that lie at the heart of informal social security. Strengthening coping mechanisms should not be considered an endorsement of the State's abdication from its social security responsibilities. To this end, the State should, besides its current social security provision endeavours, play a leading role by setting up a support framework. This could essentially include educational, financial and technical assistance. Regrettably, South Africa is still at the dawn of this significant task.

\section{BIBLIOGRAPHY}

ANDERSON, A.

1995. Challenges and prospects for research into African Initiated Churches in Southern Africa. Missionalia 23:283-294.

Prophetic healing and the growth of the Zion Christian Church in South Africa. [Online.] Retrieved from: http://artsweb.bham.ac.uk [2005, 7 September].

APt, N.A.

2000. Ageing in Africa. Paper prepared for the World Congress on Medicine and Health, Hanover.

s.a. Rapid urbanisation and living arrangements of older persons. [Online.] Retrieved from: http://www.un.org/esa/population/publications/bulletin42_43/apt.pdf [2005, 7 September].

Asian Development Bank

s.a. Social Protection: Reducing risks, increasing opportunities. [Online.] Retrieved from: http://www.adb.org/SocialProtection/default.asp [2005, 7 September]. 
BAK, $\mathrm{M}$.

2004. Can developmental welfare change an unfair world? The South African experience. International Social Work 47(1):81-94.

BARRIE, G.N.

2000. Ubuntu ungamuntu ngabanye abantu: The recognition of minority rights in the South African constitution. Tydskrif vir die Suid Afrikaanse Reg 2:271-278.

Bertrand M., Mullainatian S. \& Miller, D.

2003. Public policy and extended families: Evidence from pensions in South Africa. World Bank Economic Review 17(1):27-50.

BongmBA, E.K.

2003. Christian reform movements. In: P.T. Zeleza \& D. Eyoh (eds.), Encyclopedia of Twentieth-Century African History (London: Routledge), pp. 77-83.

ChirWa, D.M.

2002. Obligations of non-State actors in relations to economic, social and cultural rights under the South African Constitution. Bellvile: Community Law Centre, University of the Western Cape.

$\mathrm{CHURCH}, \mathrm{J}$.

1982. The black family and the law. In: F. Bosman, (ed.), Social Welfare Law (Johannesburg: Lex Patria), pp. 287-312.

CLARK, B.

2000. Child maintenance and the role of the South African state. International Journal of Children's Rights 8(4):307-320.

CLAY, D.C. \& VAN DER HAAR, J.E.

1993. Patterns of intergenerational support and childbearing in the third word. Population Studies 47(1):67-83.

Cовван, J.A.M.

1987. African values and the human rights debate: An African perspective. Human Rights Quarterly 9(3):309-331.

Committee of Inquiry into a Comprehensive System of Social Security for South AfricA

2002. Transforming the present - Protecting the future: Consolidated report. Pretoria: Committee of Inquiry into a Comprehensive System of Social Security for South Africa.

Duflo, E.

2003. Grandmothers and granddaughters: Old-age pensions and intra-household allocation in South Africa. World Bank Economic Review 17(1):1-25.

EJIzU, C.I.

s.a. African Traditional Religions and the promotion of community-living in Africa. [Online.] Retrieved from: http://www.afrikaworld.net/afrel/community.htm [2005, 7 September]. 
FITZPATRICK, D.

1900. Non-Christian marriage. Journal of the Society of Comparative Legislation 2(2):359-387.

1901. Non-Christian marriage (second article). Journal of the Society of Comparative Legislation 3(2):157-203.

Folbre, N.

1993. Women and social security in Latin America, the Caribbean and Sub-Saharan Africa. Geneva: International Labour Office.

Gerdes, V.

1975. Precursors of modern social security in indigenous African institutions. Journal of Modern African Studies 13(2):209-228.

HARRIS, T.J.

1990. Social security and its antidote. Antithesis. [Online.] Retrieved from: http://www. reformed.org/webfiles/antithesis/v1n1/ant_v1n1_socsec.html [2005, 7 September].

HAYES, S.

1992. The African Independent Churches: Judgment through terminology? Missionalia 20(2):139-146.

INTERNATIONAL LABOUR ORGANIZATION 2000. HIV/AIDS: A threat to decent work, productivity and development. Geneva: International Labour Office.

IsIzOH, C.D.

2003. African traditional religions: One stereotype less. [Online.] African Societies 4. Retrieved from: http://www.africansocieties.org/n4/eng/chidi.htm [2005, 7 September].

Kamara, G.M.

2000. Regaining our African aesthetics and essence through our African traditional religion. Journal of Black Studies 30(4):502-514.

KASEKE, E.

2002. Informal social security in Eastern and Southern Africa. In: Towards the Development of Social Protection in the SADC Region (Johannesburg: Centre for International and Comparative Labour and Social Security Law), pp. 242-250.

KOKOLE, O.H.

1994. The politics of fertility in Africa. Population and Development Review 20(1): 73-88.

LEVIN, J.

1939. Some consequences of marriage by native Christians in British Africa. Modern Law Review 3(1):48-52.

Louw, D.J.

2001. Ubuntu and the challenges of multiculturalism in post-apartheid South Africa.

Quest: An African Journal of Philosophy 15(1-2):15-36. 
Louw, L. \& KoegelenBerg, R.

2003. Building a new South Africa: The building of a caring, democratic and equitable society through partnerships between the State and the National Religious Leaders' Forum (NRLF). Position paper prepared for the NRLF meeting with President Thabo Mbeki.

Maes, A.

2003. Informal economic and social security in sub-Saharan Africa. International Social Security Review 56(3-4):39-58.

Malmotra, R. \& Kabeer, N.

2002. Demographic transition, inter-generational contracts and old age security: An emerging challenge for social policy in developing countries. Institute of Development Studies.

MaziBuko, B.A.

1996. Mutual sharing as liberation of 'Mainline' and Independent Churches. In: M.C. Kitshoff, (ed.), African Independent Churches today: Kaleidoscope of Afro-Christianity (Lewiston: Edwin Mellen Press), pp. 249-264.

MCKENDRICK, B. \& DUdAs, E. 1987. South Africa. In: J. Dixon (ed.), Social Welfare in Africa (Kent: Croom Helm), pp. 184-217.

Mokgoro, J.Y.

2007. Ubuntu and the law in South Africa. Paper presented at the first Colloquium: Constitution and Law, held in Potchefstroom, South Africa.

MPEDI, L.G.

2004. HIV/AIDS in South Africa: Towards comprehensive social protection? Zeitschrift für auslandisches und internationales Arbeits- und Sozialrecht (ZIAS) 18(3):243-270.

Mpedi, L.G, Kuppan, G.Y. \& Olivier, M.P. 2003. Welfare and legal aid. In: M.P. Olivier, N. Smit, \& E.R. Kalula (eds.), Social security: A legal analysis. Durban (LexisNexis/Butterworths), pp. 197-230.

Mutangadura, G.B. 2001. Women and AIDS in Southern Africa: The case of Zimbabwe and its policy implications. Jenda: A Journal of Culture and African Women Studies 1:1-11.

Nattrass, N. \& Seekings, J. 1997. Citizenship and welfare in South Africa: Deracialisation and inequality in labour surplus economy. Canadian Journal of African Studies 31(3):452-481.

NORTON, G.R.

1941. The emergence of new religious organisations in South Africa: A discussion of causes (Part II). Journal of the Royal African Society 40(158):48-67. 
Oкоцо, C.B.

s.a. Urbanization and African traditional values. In: J. Kromkowski \& G.F. McLean (eds.), Urbanization and values. Cultural heritage and contemporary change. [Online.] Retrieved from: http://www.crvp.org/book/Series01//-5/chapter_ix.htm [2005, 7 September].

OLIVIER, M.

2001. Towards social protection: Lessons from a comparative perspective. In: D. Pieters (ed.), Confidence and changes: Managing social protection in the new millennium (The Hague: Kluwer Law), pp. 277-301.

Olivier, M. \& DeKKer, A.H.

2003. Informal social security. In: M. Olivier, N. Smit, \& E.R. Kalula (eds.), Social security: A legal analysis (Durban: LexisNexis/Butterworths), pp. 559-593.

OLIVIER, M.P.

2003. Death and survivors' benefits. In: M. Olivier, N. Smit, \& E.R. Kalula (eds.), Social security: A legal analysis (Durban: LexisNexis/Butterworths), pp. 301-310.

Olivier, M.P. \& Kalula, E.R.

2004. Legal framework and scope of coverage. In: M.P. Olivier, N. Smit, E.R. Kalula \& G.C.Z. Mhone (eds.), Introduction to social security (Durban: LexisNexis/Butterworths), pp. 33-53.

OlivieR, M.P. \& MPEDI, L.G.

2003. Extending social protection to families in the African context: The complementary role of formal and informal social security. Paper presented at the $4^{\text {th }}$ International Research Conference on Social Security, Antwerp, Belgium.

Olivier, M.P., Kaseke, E. \& Mpedi, L.G.

2004. Formulating an integrated social security response - Perspectives on developing links between informal and formal social security in SADC region. Paper presented at the EGDI-WIDER Conference on Unlocking Human Potential Linking the Informal and Formal Sectors, Helsinki.

Olivier M.P., Khoza, J.F., Jansen van Rensburg, L. \& Klinck, E. 2003. Constitutional issues. In: M. P. Olivier, N. Smit \& E.R. Kalula (eds.), Social security: A legal analysis (Durban: LexisNexis/Butterworths), pp. 49-121.

Pieterse, E. \& Van Donk, M. 2002. Realising socio-economic rights: The role of the state and civil society. Economic and Social Rights Review 3. [Online.] Retrieved from: http://communitylawcentre.org.za/ser/esr 2002/2002july_civil.php [2005, 7 September].

Rautenbach, C. \& Goolam, N.M.I. (Eds.) 2002. Introduction to legal pluralism in South Africa: Part II - Religious legal systems. Durban. Butterworths.

ROBERTS, B.

2000. Africa-morality: South Africa needs moral renewal. [Online.] Agence FrancePresse. Retrieved from: http://www.aegis.com [2005, 7 September]. 
SCHIRRMACHER, T.

1997. Social responsibility in the New Testament church according to Acts 6. [Online.] Retrieved from: http://www.contra-mundmum.org/schirrmacher/social_acts6. html [2005, 7 September].

SONGUEMAS, $\mathrm{N}$.

1967. Social security and indigenous institutions in African societies. African Social Security Series 3:18-27.

Statistics South Africa 2007. Labour force survey: 2007. Pretoria: Statistics South Africa.

SUDARKASA, N. 1980. African and Afro-American family structure: A comparison. Journal of Black Studies and Research 11(8):37-60.

Unaids/World Health Organization 2004. AIDS Epidemic Update: December 2004. Geneva: UNIADS/World Health Organization.

VALODIA, I.

2001. Economic policy and women's informal work in South Africa. Development and Change 32(5):871-892.

VAN DER VYVER, J.D. 1999. Constitutional perspective of church-state relationship in South Africa. Brigham Young University Law Review 2:635-673.

Keywords

South Africa

Social protection

Religious values
Trefwoorde

Suid-Afrika

Sosiale veiligheid

Godsdienstige waardes 